九病虫研会報 $60: 75-78(2014)$

Kyushu Pl. Prot. Res. 60 : 75-78（2014）

\title{
鹿児島県内におけるコナガのジアミド系 殺虫剤に対する感受性低下
}

\author{
福田 健 ${ }^{\dagger} \cdot$ 林川 修二* \\ （鹿児島県農業開発総合センター大隅支場）
}

\begin{abstract}
Decline in susceptibility to diamide insecticides of the diamondback moth, Plutella xylostella L.(Lepidoptera), collected in Kagoshima Prefecture. Takeshi Fukuda ${ }^{\dagger}$ and Shuji Hayashikawa* (Kagoshima Prefectural Institute for Agricultural Development, Osumi Branch, Kanoya, Kagoshima 893-1601, Japan)
\end{abstract}

鹿児島県内のキャベッほ場で採集したコナガ 2 個体群に対する 26 殺虫剤の殺虫効果を検討した。 その結果, カルタップ水溶剤, エマメクチン安息香酸塩乳剂, レピメクチン乳剂, スピノサド水 和剤，スピネトラム水和剤，デルフィン水和剤，ゼンターリ水和剂，メタフルミゾンフロアブル およびインドキサカルブ水和剤は 2 個体群での補正死虫率が高かった。一方，ジアミド系殺虫剤 であるフルベンジアミド水和剤およびクロラントラニリプロールフロアブルは高い殺虫効果を示 さなかった。さらに，この 2 殺虫剤に対する $\mathrm{LC}_{50}$ 值を調査した結果，フルベンジアミド水和剤で は曽於個体群が $>200 \mathrm{ppm}$, 鹿屋個体群が $6.17 \mathrm{ppm}$ で, 感受性比（R/S）はそれぞれ>50,000, 1,543，クロラントラニリプロールフロアブルは曽於個体群が> $>50 \mathrm{ppm}$, 鹿屋個体群が4.93ppm で, 感受性比は（R/S）はそれぞれ>556，55で，両剤に対する感受性低下が認められた。

Keywords : susceptibility, R/S ratio, leaf disk dipping method, Flubendiamide, Chlorantraniliprole

緒 言

アブラナ科野菜の重要害虫であるコナガの防除は, 1970年代中頃から有機リン剤の効力低下が問題になり （東海林・野村，1975），1980年代からはカーバメート 剤への抵抗性が顕在化した（浜, 1983, $1986 \mathrm{a})$ 。そ の後，合成ピレスロイド剂に対しても抵抗性の発達が みられ（牧野・堀切, 1985 ; 堀切・牧野, 1987), 1980年代後半にはキチン合成阻害剂に対して高い抵抗 性を示すなど（田中ら，1992；末永ら，1992）, 薬剤 防除が困難な害虫であった。しかし，1990年代後半か ら効果の高いクロルフェナピル水和剤やエマメクチン 安息香酸塩乳剤およびジアミド系殺虫剤などが登録さ れ，これらの殺虫剤の使用により，鹿児島県に扔ける アブラナ科野菜でのコナガの発生抢よび被害が目立た

† fukuda-takesi@pref.kagoshima.lg.jp

* 現在 鹿児島県農業開発総合センター

* Present address : Kagoshima Prefectural Institute for Agricultural Development, Minamisatsuma, Kagoshima 899-3401, Japan
なくなった。ところが，2013年に曽於市のアブラナ科 野菜でコナガによる被害が発生した。コナガの発生原 因の一つとして各種殺虫剤の効果の低下が考えられる ことから，防除対策を講じる上では，薬剤感受性の把 握が重要となる。そこで, 鹿児島県内 2 地点で採集し た個体群を対象に，各種殺虫剂に対する殺虫効果およ び薬剂感受性を調査した。その結果, 従来高い殺虫効 果を示してきたジアミド系殺虫剂に対して，本県では 初めてコナガの感受性低下が認められた。

\section{材料および方 法}

\section{1，供試虫個体群および殺虫剤}

曽於個体群は2013年12月 3 日に鹿児島県曽於市キャ ベッほ場から，鹿屋個体群は2013年12月18日にこれま でコナガ防除下で大きな発生が認められていなかった 鹿児島県農業開発総合センター大隅支場（同鹿屋市） キャベッほ場からそれぞれ幼虫および蛹を採集した。 各個体群の採集数は曽於個体群が200頭以上，鹿屋個 体群が100頭以上であった。曽於個体群は次世代の 3 齢幼虫, 鹿屋個体群は第二世代の 3 齢幼虫を供試した。 なお, 供試虫はダイコン芽出し苗（品種：「大阪四十 
日大根」）を用いて， $25^{\circ} \mathrm{C} ， 14 \mathrm{~L} 10 \mathrm{D}$ の室内で飼育した。 第 1 表に示した市販されている26殺虫剂を常用濃度に 希釈し, 全ての供試殺虫剤に展着剂（ミックスパ ワー®5000倍）を加用した。

\section{2. 幼虫に対する各種殺虫剤の殺虫効果}

検定方法には葉片浸漬法を用いた。すなわち，キャ ベツ（品種：「金系201号」）の葉を直径 $8 \mathrm{~cm}$ に切り 取り，希釈した薬液に 30 秒間浸漬した。処理葉は風乾 後に，ろ紙を敷いた直径 $9 \mathrm{~cm}$ のプラスチックシャー レ内に移し， 3 齢幼虫を10頭ずつ放飼した。その後, $25^{\circ} \mathrm{C}, 14 \mathrm{~L} 10 \mathrm{D}$ の恒温室に収容し, BT 剂は96時間後に, その他の剤は72時間後に放飼した幼虫の生死を調査し, 補正死虫率を求めた。試験は 3 反復で行った。

\section{3. 幼虫に対するジアミド系殺虫剤の $\mathrm{LC}_{50}$ 值}

供試殺虫剂を 2 倍毎に 5 ～6段階に希釈した薬液に, 展着剂（ミックスパワー ®5000倍）を加用した。殺 虫効果試験と同様の葉片浸漬法で 3 齢幼虫の補正死虫 率を求めた。得られた 72 時間後の補正死虫率をもとに プロビット法で $\mathrm{LC}_{50}$ 值を算出し，フルベンジアミド 水和剂に対する感受性個体群 (1967年に大阪府で採集； 採集作物は不明)，クロラントラニリプロールフロア ブルに対する感受性個体群（1964年に埼玉県のキャべ ツほ場で採集）の $\mathrm{LC}_{50}$ 值とそれぞれ比較した。

\section{結果}

\section{1．幼虫に対する各種殺虫剤の殺虫効果}

コナガ 3 齢幼虫に対する各種殺虫剂の殺虫効果を第 1 表に示した。

ジアミド系殺虫剤のフルベンジアミド水和剤は，補 正死虫率が曾於個体群で $13 \%$ ，鹿屋個体群で $62 \%$ ，ク ロラントラニリプロールフロアブルは曽於個体群が $23 \%$ ，鹿屋個体群が70\%で，両剤は 2 個体群に対して 高い殺虫効果が認められなかった。

有機リン系殺虫剤のアセフェート水和剤は, 補正死 虫率が曾於個体群で $53 \%$, 鹿屋個体群で $76 \%$ ，プロチ オホス乳剂は曽於個体群が30\%, 鹿屋個体群が73\%で, 曽於個体群に対して殺虫効果は低く, 鹿屋個体群に対 する効果はみられるがやや低かった。

合成ピレスロイド系殺虫剤のエトフェンプロックス 乳剂㧍よびシペルメトリン乳剂は，2 個体群とも補正 死虫率が $30 \%$ 以下で，殺虫効果が低かった。

カーバメート系殺虫剤のメソミル水和剤の補正死虫 率は曽於個体群が $23 \%$ ，鹿屋個体群が $31 \%$ で，2個体 群に対する殺虫効果は低かった。

ネライストキシン系殺虫剤のカルタップ水溶剤は,
2 個体群とも補正死虫率が $100 \%$ で, 高い殺虫効果が 認められた。

キチン合成阻害剤の 3 剂での補正死虫率は曾於個体 群では10〜20\%と低かったが，鹿屋個体群では90〜 $100 \%$ と高く，2 個体群で殺虫効果が顕著に異なった。

ネオニコチノイド系殺虫剤のクロチアニジン水溶剤 の補正死虫率は曽於個体群が $13 \%$ ，鹿屋個体群が $10 \%$ と低く，アセタミプリド水溶剤は曽於個体群が $20 \%$, 鹿屋個体群が53\%で，2 個体群に対する殺虫効果は低 かった。

フェニルピラゾール系殺虫剤のフィプロニルフロア ブルの補正死虫率は鹿屋個体群で $91 \%$ と殺虫効果が認 められたが，曽於個体群に対しては殺虫効果が低かっ た。

マクロライド系殺虫剤の補正死虫率は 2 個体群とも 高く, 特に，スピノサド水和剤抢よびスピネトラム水 和剤の補正死虫率は $100 \%$ であった。

$\mathrm{BT}$ 剂のデルフィン水和剂，ゼンターリ水和剂も 2 個体群の補正死虫率が88～100\%で，高い殺虫効果を 示した。

その他の系統殺虫剤では, メタフルミゾンフロアブ ル，インドキサカルブ水和剤の 2 郕は高い殺虫効果が 認められ，補正死虫率が86〜100\%であった。

\section{2. 幼虫に対するジアミド系殺虫剤の $L C_{50}$ 值}

フルベンジアミド水和剂の $\mathrm{LC}_{50}$ 值は, 感受性個体 群が0.004ppm であったのに対して，曽於個体群が> $200 \mathrm{ppm}$, 鹿屋個体群が6.17ppm で, 感受性比 (R/S)

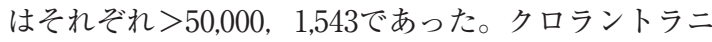
リプロールフロアブルの $\mathrm{LC}_{50}$ 值は感受性個体群が $0.09 \mathrm{ppm}$ であったのに対して, 曽於個体群が>50ppm, 鹿屋個体群が4.93ppm で, 感受性比は（R/S）はそれ ぞれ>556，55であった（第 2 表）。

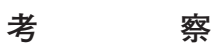

コナガのジアミド系殺虫剤に対する感受性の低下は, 海外では夕イ国で（Sukonthabhirom et al., 2009），国 内では大分県や千葉県の個体群で認められている（上 島ら，2014；清水ら，2014）。本試験ではキャベッか ら採集したコナガ 2 個体群に対してフルベンジアミド 水和剂㧍よびクロラントラニリプロールフロアブルは 高い殺虫効果を示さなかった（第 1 表）。さらに，両 剂の $\mathrm{LC}_{50}$ 值は, 感受性個体群よりも 2 個体群の值が 高く (第 2 表)，鹿児島県でもジアミド系殺虫剤に対 して感受性の低下した個体群の存在が明らかとなり， これがアブラナ科野菜でコナガの多発した一因と考え 
第 1 表 コナガ 3 齢幼虫に対する各種殺虫剤の殺虫効果

\begin{tabular}{|c|c|c|c|c|c|}
\hline \multirow{2}{*}{ 供試殺虫剂名 } & \multirow[t]{2}{*}{ 剂型 } & \multirow{2}{*}{$\begin{array}{c}\text { 成分量 } \\
(\%)\end{array}$} & \multirow[t]{2}{*}{ 希釈倍数 } & \multicolumn{2}{|c|}{ 補正死虫率（\%） } \\
\hline & & & & 曽於個体群 & 鹿屋個体群 \\
\hline \multicolumn{6}{|l|}{ ジアミド系 } \\
\hline フルベンジアミド & 水和剂 & 20 & 2,000 & 13.3 & 62.5 \\
\hline クロラントラニリプロール & フロアブル & 5 & 2,000 & 23.3 & 70.0 \\
\hline \multicolumn{6}{|l|}{ 有機リン系 } \\
\hline アセフェート & 水和剤 & 50 & 1,000 & 53.3 & 76.7 \\
\hline プロチオホス & 乳剤 & 45 & 1,000 & 30.7 & 73.4 \\
\hline \multicolumn{6}{|l|}{ 合成ピレスロイド系 } \\
\hline エトフェンプロックス & 乳剂 & 20 & 1,000 & 26.7 & 13.3 \\
\hline シペルメトリン & 乳剤 & 6 & 1,000 & 6.7 & 0.0 \\
\hline \multicolumn{6}{|l|}{ カーバメート系 } \\
\hline メソミル & 水和剤 & 45 & 1,000 & 23.3 & 31.6 \\
\hline \multicolumn{6}{|l|}{ ネライストキシン系 } \\
\hline カルタップ & 水和剤 & 75 & 1,500 & 100 & 100 \\
\hline \multicolumn{6}{|l|}{ キチン合成阻害剂 } \\
\hline クロルフルアズロン & 乳剤 & 5 & 2,000 & 10.0 & 90.0 \\
\hline フルフェノクスロン & 乳剤 & 10 & 2,000 & 20.0 & 100 \\
\hline テフルベンズロン & 乳剂 & 5 & 2,000 & 10.1 & 95.8 \\
\hline \multicolumn{6}{|l|}{ ネオニコチノイド系 } \\
\hline クロチアニジン & 水和剤 & 16 & 2,000 & 13.3 & 10.0 \\
\hline アセタミプリド & 水和剤 & 20 & 2,000 & 20.0 & 53.3 \\
\hline \multicolumn{6}{|l|}{ フェニルピラゾール系 } \\
\hline フィプロニル & フロアブル & 5 & 2,000 & 56.7 & 91.7 \\
\hline \multicolumn{6}{|l|}{ マクロライド系 } \\
\hline エマメクチン安息香酸塩 & 乳剤 & 1 & 1,000 & 93.3 & 100 \\
\hline レピメクチン & 乳剤 & 1 & 1,000 & 86.7 & 95.8 \\
\hline スピノサド & 水和剤 & 25 & 2,500 & 100 & 100 \\
\hline スピネトラム & 水和剤 & 11.7 & 2,500 & 100 & 100 \\
\hline \multicolumn{6}{|l|}{ BT 剤 } \\
\hline \multicolumn{6}{|l|}{ kurustaki 生菌 } \\
\hline デルフィン & 水和剤 & 10 & 1,000 & 96.7 & 100 \\
\hline \multicolumn{6}{|l|}{ aizawai 生菌 } \\
\hline ゼンターリ & 水和剤 & 10 & 1,000 & 93.3 & 88.3 \\
\hline \multicolumn{6}{|l|}{ その他 } \\
\hline クロルフェナピル & フロアブル & 10 & 2,000 & 26.7 & 96.5 \\
\hline ピリダリル & フロアブル & 10 & 1,000 & 87.3 & 78.3 \\
\hline インドキサカルブ & 水和剂 & 5 & 2,000 & 100 & 96.7 \\
\hline メタフルミゾン & フロアブル & 25 & 1,000 & 86.7 & 92.5 \\
\hline トルフェンピラド & 乳剤 & 15 & 1,000 & 50.0 & 66.7 \\
\hline \multicolumn{6}{|l|}{ トルフェンピラド・ } \\
\hline メタフルミゾン & フロアブル & $12+19$ & 1,000 & 63.3 & 84.6 \\
\hline
\end{tabular}

a) BT 剂は処理96時間後, その他の殺虫剤は処理72時間後の補正死虫率を示す.

第2 表 コナガの感受性系統と野外 2 個体群に対するジアミド系殺虫剤の $\mathrm{LC}_{50}$ 值

\begin{tabular}{|c|c|c|c|c|c|}
\hline 殺虫剤名·剽型 & $\begin{array}{c}\text { 感受性系統 }{ }^{\text {a })} \\
(\mathrm{ppm})\end{array}$ & $\begin{array}{l}\text { 曽於 } \\
(\mathrm{ppm})\end{array}$ & $\begin{array}{c}\text { 感受性比 } \\
(\mathrm{R} / \mathrm{S})\end{array}$ & $\begin{array}{c}\text { 鹿屋 } \\
(\mathrm{ppm})\end{array}$ & $\begin{array}{c}\text { 感受性比 } \\
(\mathrm{R} / \mathrm{S})\end{array}$ \\
\hline フルベンジアミド水和剤 & 0.004 & $>200$ & $>50,000$ & 6.17 & 1,543 \\
\hline クロラントラニリプロールフロアブル & 0.09 & $>50$ & 556 & 4.93 & 55 \\
\hline
\end{tabular}

a) フルベンジアミド水和剤に供試した感受性系統は1967年に大阪府で採集された個体群. クロラントラニリプロールフロアブルに供試した感受性系統 は1964年に埼玉県で採集された個体群。 
られた。

合成ピレスロイド系のエトフェンプロックス乳剤お よびシペルメトリン乳剂, カーバメート系のメソミル 水和剤では補正死虫率が低かった。鹿児島県では 1980 年代に合成ピレスロイド系およびカーバメート系殺虫 剤の感受性低下が報告されており（牧野・堀切, 1985 ; 堀切, 1989), これらの殺虫剤に対するコナガ の感受性は1980年代から変化がないと推察される。

鹿児島県霧島市溝辺町では1980年代後半にキチン合 成阻害剤に対するコナガの抵抗性発達が認められた (田中ら，1992；末永ら，1992）。本試験での曽於個体 群は，キチン合成阻害剂についてこれらの報告と同様 の感受性低下が認められた。一方，鹿屋個体群に対し て高い殺虫効果を示した。薬剤抵抗性の有無や発達程 度は, 個体群が発生している地域で使用された薬剤の 種類やその散布回数に依存し, 地域間差を生じること が指摘されている（浜，1986 b ）。今回，両地点で個 体群の感受性に違いが生じたのは，このような理由に よるものと考えられた。

本県のキャベツおよびハクサイ栽培では，ジアミド 系殺虫剤のクロラントラニリプロール剂の育苗期灌注 処理やフルベンジアミド水和剂の散布処理がコナガの 基幹防除剤として定着している。今後は他の地域の個 体群についても検定を行いながら，ジアミド系殺虫剤 に対して感受性低下がみられる地域でのコナガの防除 を考慮した新たな防除体系を早急に構築する必要があ る。

\section{引用 文 献}

浜 弘司（1983）コナガの殺虫剤抵抗性. 植物防疫 $37: 471-476$.

浜 弘司 $(1986 \mathrm{a})$ コナガの薬剤抵抗性. 植物防疫 $40: 366-372$.

浜 弘司 $(1986$ b ) 各種殺虫剤に対するコナガの抵抗
性スペクトル。応動昆 $30 ： 277-284$.

堀切正俊・牧野 晋 (1987) 鹿児島県におけるコナガ

の薬剤抵抗性について。 九病虫研会報 $33: 131$ 135 .

堀切正俊 (1989) コナガの体系防除. 九病虫研会報 $35: 96-99$.

牧野 晋・堀切正俊（1985）コナガの合成ピレスロイ ドに対する感受性の低下について。 九病虫研会報 $31: 175-178$.

清水 健 - 大谷 徹 - 河名利幸 - 遠藤正樹 (2014）千 葉県コナガ個体群におけるジアミド系殺虫剂への感 受性．関東東山病虫研報 $61 ： 9$ 。(講要)

東海林修・野村健一（1975）コナガ 3 系統に対する D DVP 抢よびBT 剂の効果比較. 応動昆 19：298〜 299.

末永 博 - 田中 章 - 村田麻美 · 堀切正俊 (1992）鹿 児島県に㧍けるコナガのキチン合成阻害剂抵抗性発 達 : 第 2 報. 感受性検定. 九病虫研会報 $38: 129$ 131 .

Sukonthabhirom, S., D. Dumrongsak, S. Jumroon, T. Saroch, A. Chaweng and T. Tanaka (2009) Update on DBM diamide resistance from Thailand: causal factors and learnings. https://www.iraconline.org/wp-content/uploads/2009/09/F2FDiamide-WG-Mtg-2011_20IRACa.pdf（2014年 4 月 6 日アクセス確認

田中 章・ 未永 博 - 村田麻美・西岡稔彦・山口卓宏・ 堀切正俊（1992）鹿児島県におけるコナガのキチン 合成阻害剂抵抗性発達：第 1 報. 溝辺町に扮ける防 除効果の低下。九病虫研会報 $38: 127-128$.

上島慧理子 · 加藤幸太郎・小野元治 $(2014)$ 大分県の キャベッ産地で採集したコナガに対する各種薬剤に 殺虫効果. 応動昆 $58: 65$. (講要)

（2014年 4 月24日受領， 8 月18日受理） 